\title{
A Concise Review of Ketogenic Dietary Interventions in the Management of Rare Diseases
}

\author{
D. Hettiarachchi $\mathbb{D}^{1,2}$ K. Lakmal, ${ }^{1}$ and V. H. W. Dissanayake $\mathbb{D}^{1,2}$ \\ ${ }^{1}$ Department of Anatomy, Faculty of Medicine, University of Colombo, Colombo, Sri Lanka \\ ${ }^{2}$ Human Genetics Unit, Faculty of Medicine, University of Colombo, Colombo, Sri Lanka \\ Correspondence should be addressed to D. Hettiarachchi; dinebine@gmail.com
}

Received 23 November 2020; Revised 13 January 2021; Accepted 29 January 2021; Published 15 February 2021

Academic Editor: Chunpeng Wan

Copyright (c) 2021 D. Hettiarachchi et al. This is an open access article distributed under the Creative Commons Attribution License, which permits unrestricted use, distribution, and reproduction in any medium, provided the original work is properly cited.

Dietary interventions are now being used as an adjunct therapy in the treatment of rare diseases. One such method is the high-fat, moderate-protein, and very low-carbohydrate diet which produces ketosis and therefore called the ketogenic diet. Some of the more common conditions that are treated with this method are pharmacoresistant epilepsy, infantile spasms, glycogen storage diseases, and other forms of rare metabolic disturbances. With this review, we look at different uses of the ketogenic diet in treating rare diseases and the recommendations based on current evidence.

\section{Introduction}

There are many obstacles when treating rare diseases as they may often depict only the tip of the iceberg, which represents some varied genetic and phenotypic characteristics. Certain dietary modifications such as the ketogenic diet and the modified Atkins diet (MAD) have been tried in a plethora of rare diseases ranging from epilepsy, infantile spasms, and glycogen storage diseases to other forms of rare metabolic disturbances [1-3]. In monogenic rare diseases, a continuum of therapeutic strategies can be employed, and medical nutrition therapy is one such option. With the expansion of our understanding of the affected metabolic pathways, we can now tailor these therapies on a personalized basis [4]. A ketogenic diet is one that is typically high in fat, with moderate protein and a very low-carbohydrate levels, or it can also be high in protein and lower in fat and carbohydrate levels, with the end result of producing ketosis. This produces a form of starvation and forces the body to deviate from its traditional fuel source glucose to primarily use fats [5]. The key to a ketogenic diet is limited carbohydrate intake to a total daily amount of 10 to 50 grams or $5 \%$ to $10 \%$ of total caloric intake which causes fat to be converted to various ketone bodies for cellular metabolism (e.g., acetoacetate, beta-hydroxybutyrate, and acetone) $[6,7]$. Certain ketogenic dietary protocols use medium-chain triglycerides (MCT) to help boost ketone production as they are more rapidly broken down into ketones and energy [8]. This form of dietary modifications was documented since 1925 to treat drug-resistant epilepsy $[9,10]$. However, a prolonged ketogenic diet is not endured well as there are several drawbacks such as retardation of growth in children and gastrointestinal side effects [11]. The aim of this review is to look at the different uses of a ketogenic diet in treating rare diseases and to make recommendations based on current evidence.

\section{Pharmacoresistant Epilepsy, Infantile Spasms, and Tuberous Sclerosis}

It is estimated that $30 \%$ of epilepsy patients are pharmacoresistant. In this group of patients, a ketogenic diet (KD) has offered some promising results [12]. In experimental cell culture models such as in rat hippocampal neuronal cells, the 3 ketone bodies, namely, acetone, acetoacetic acid, and $\beta$-hydroxybutyric acid, inhibit the opening of the acidsensing ion channels through undermining their currents and, as a result, inhibit their function [11]. From the literature review done in MEDLINE, Google Scholar, and Cochrane library, six randomized control trials [13-18] have 


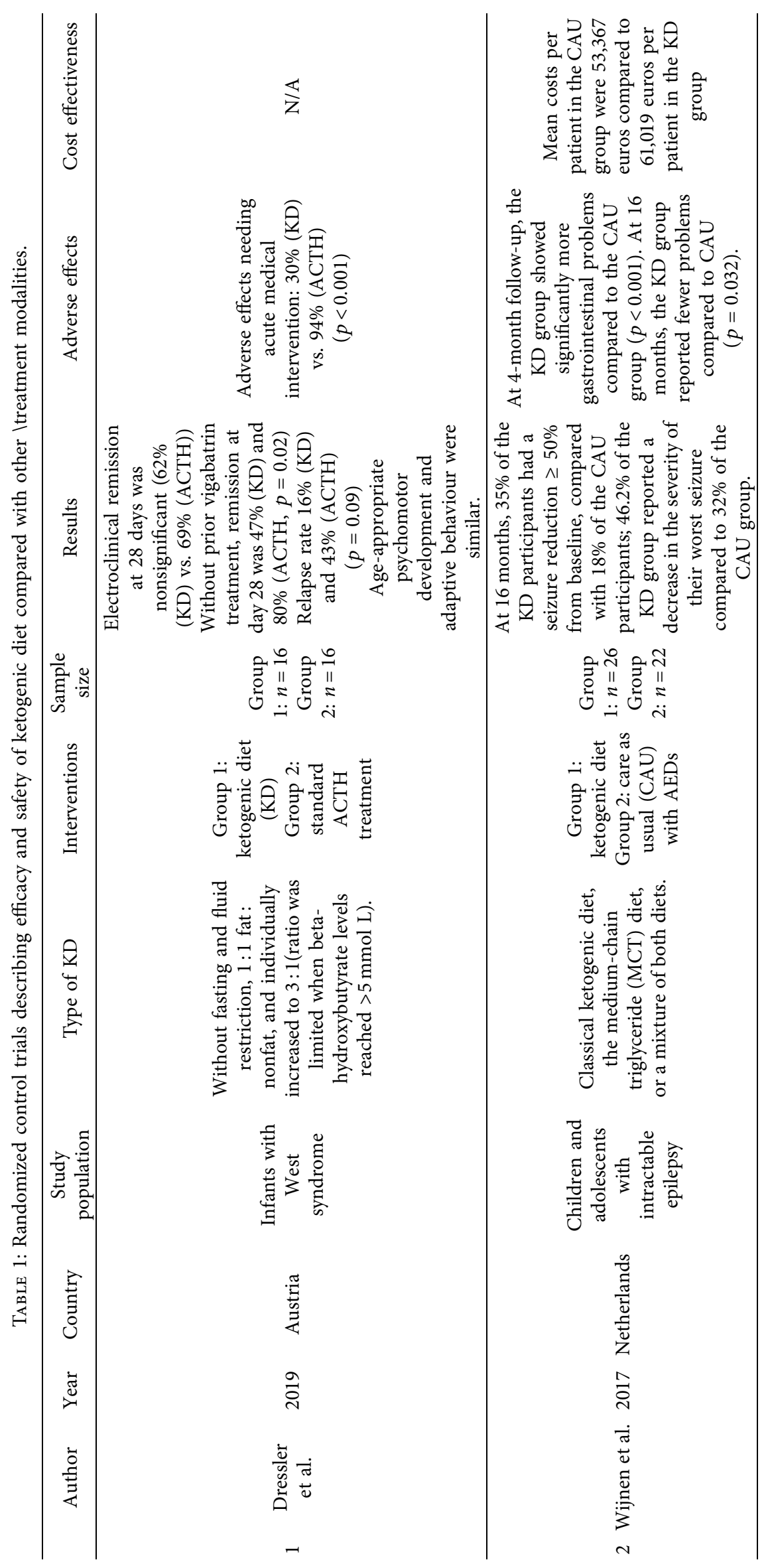




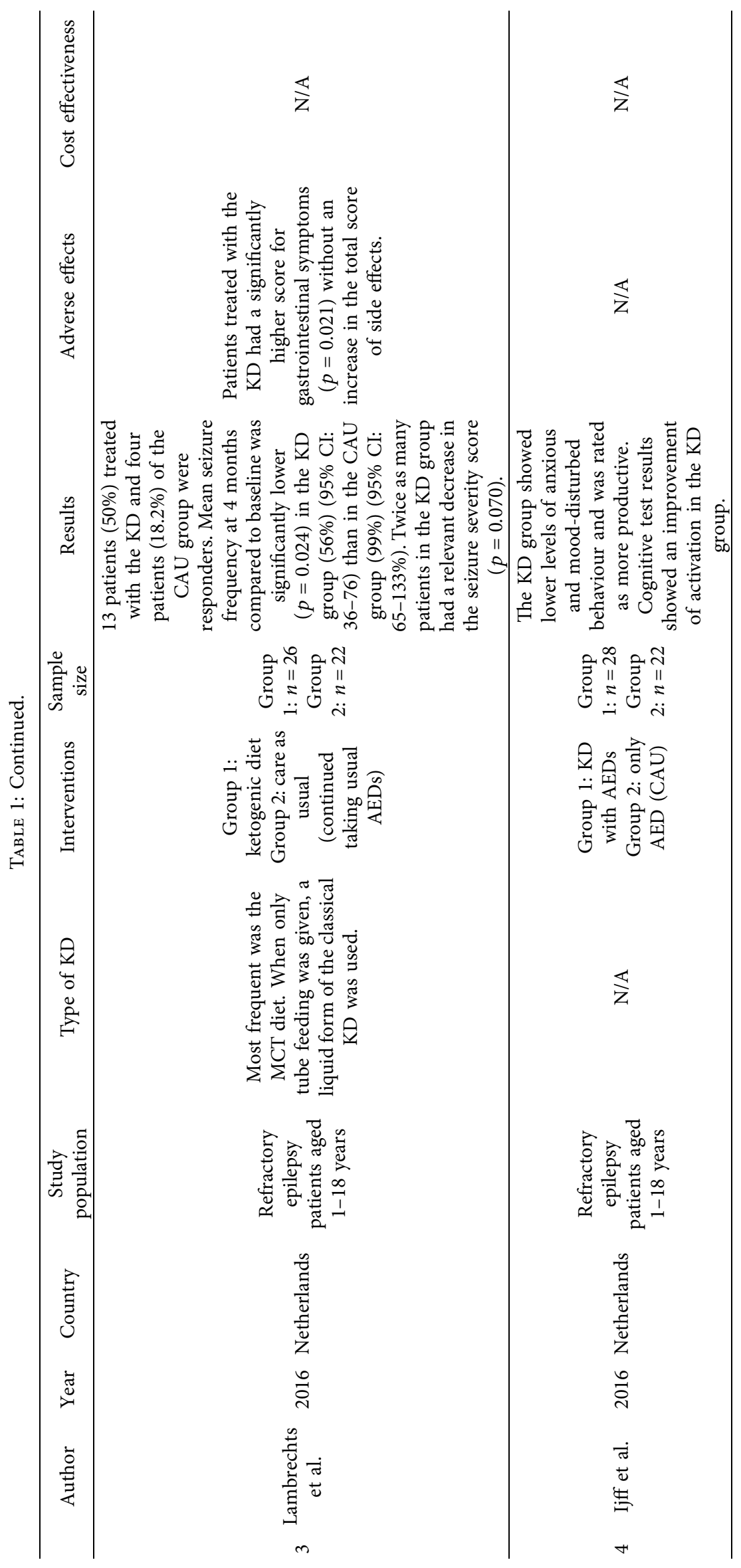




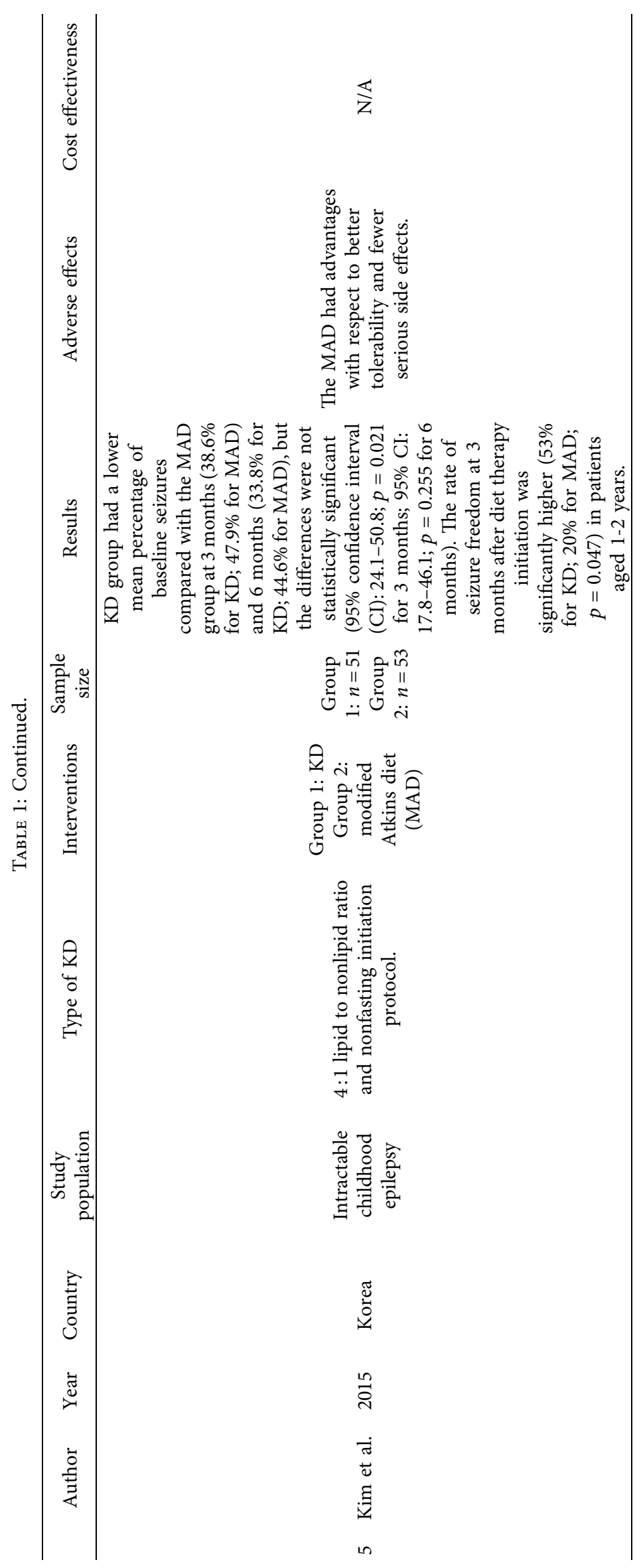




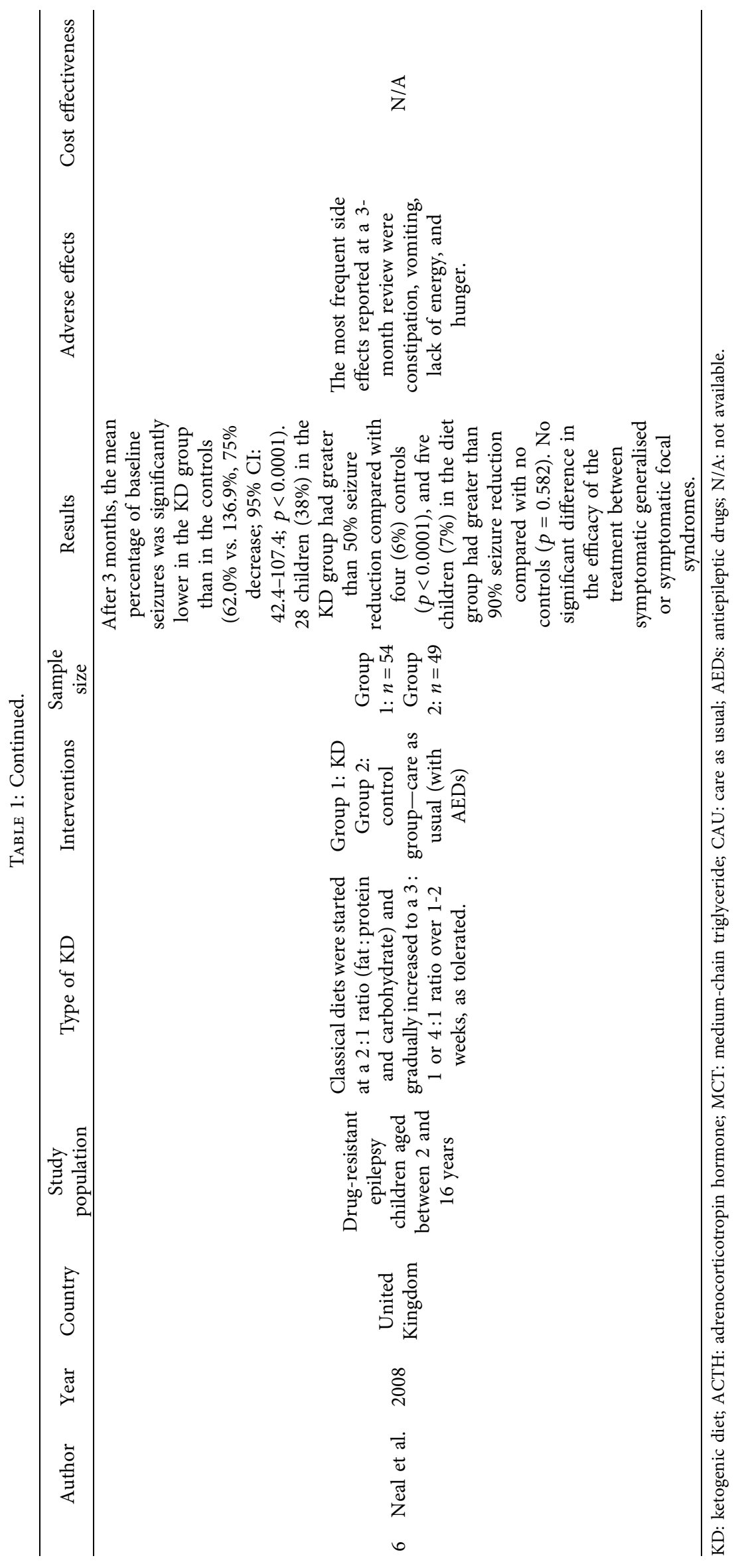




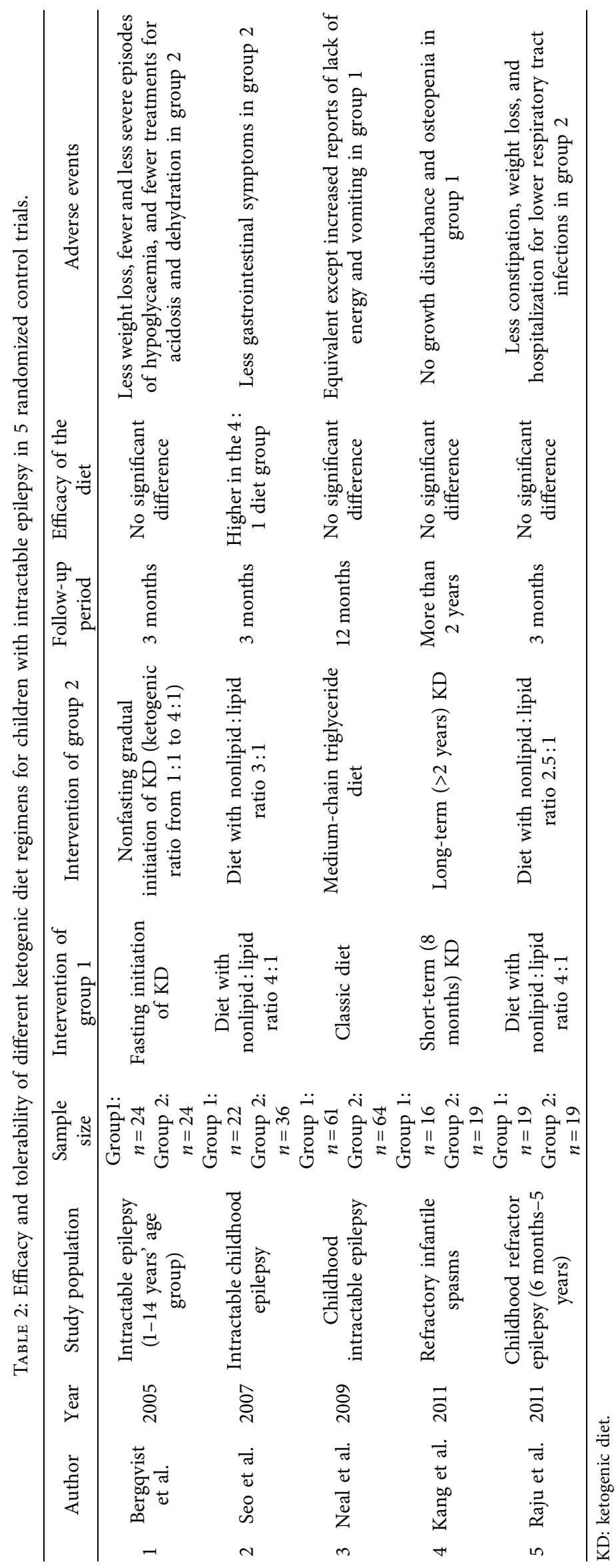




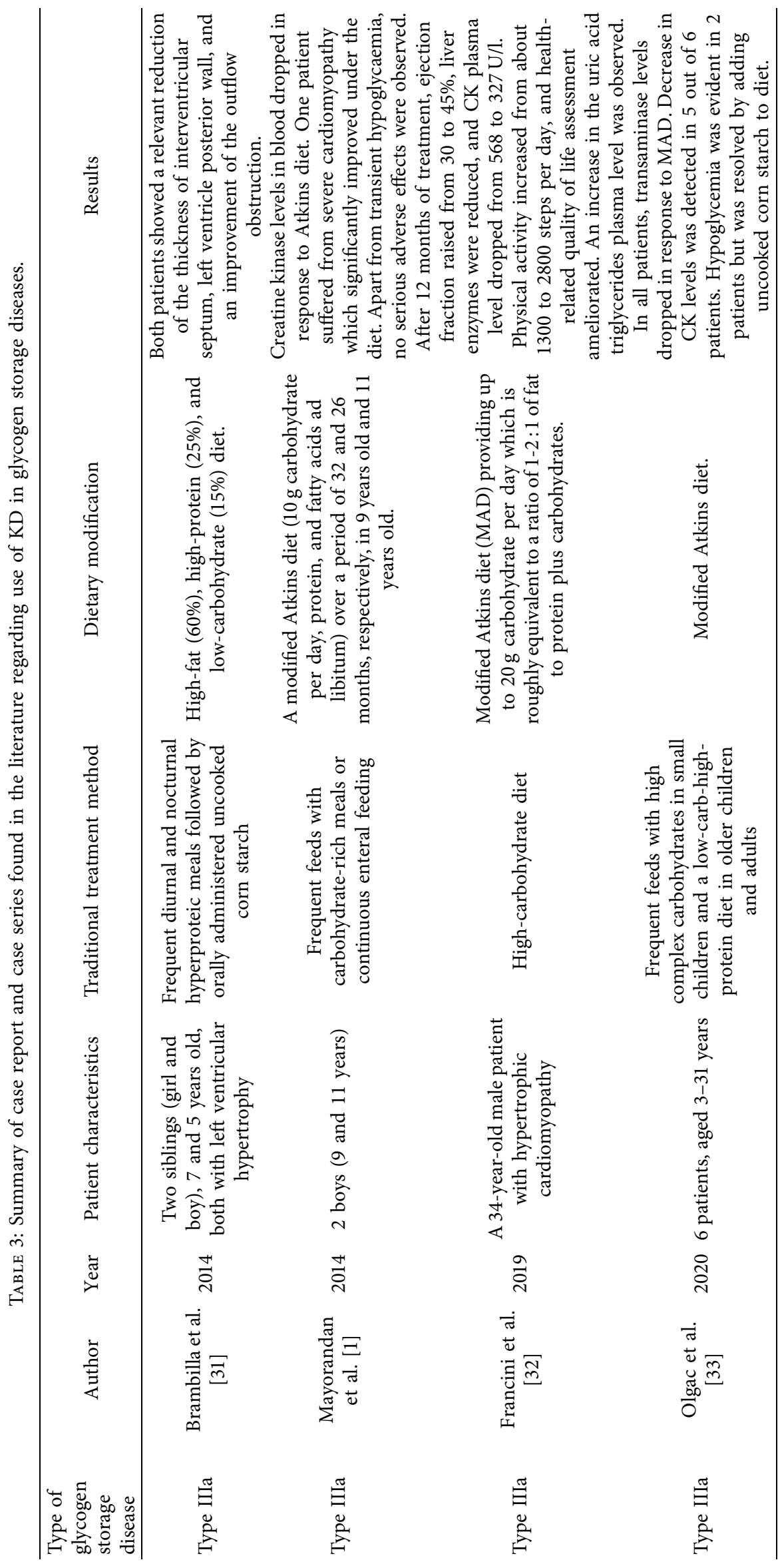




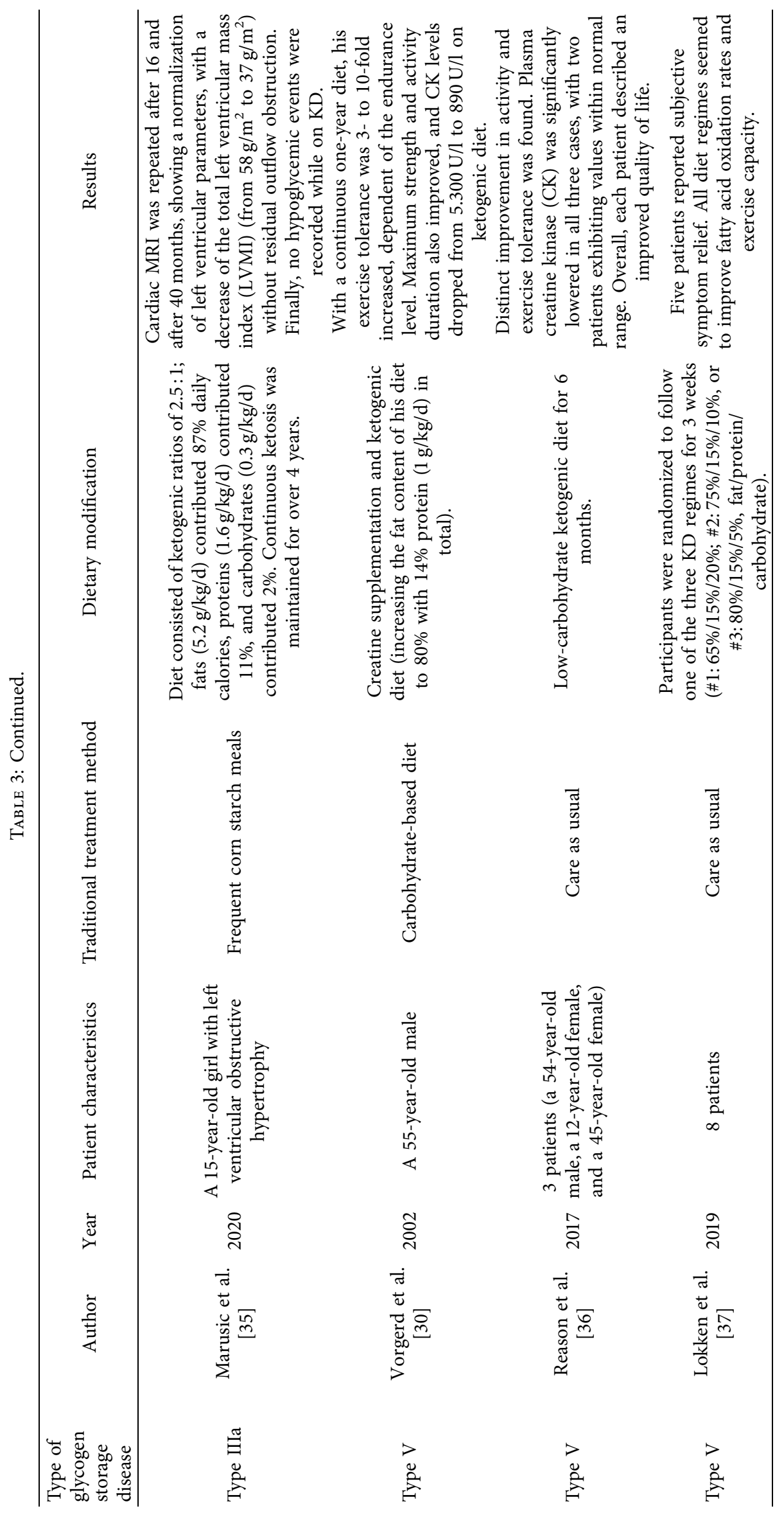


TABLE 4: Summary of case report and case series found in the literature regarding use of KD in mitochondrial disorders.

\begin{tabular}{|c|c|c|c|c|c|c|}
\hline $\begin{array}{l}\text { Mitochondrial } \\
\text { disorder }\end{array}$ & Author & Year & Patient characteristics & $\begin{array}{c}\text { Traditional } \\
\text { treatment method }\end{array}$ & Dietary modification & Results \\
\hline \multirow{3}{*}{$\begin{array}{l}\text { Pyruvate } \\
\text { dehydrogenase } \\
\text { complex } \\
\text { deficiency }\end{array}$} & $\begin{array}{l}\text { Sofou et al. } \\
\text { [41] }\end{array}$ & 1976 & $\begin{array}{l}\text { Two brothers, aged } 11 \\
\text { years } 6 \text { months and } 2 \\
\text { years } 3 \text { months, with } \\
\text { psychomotor and } \\
\text { growth retardation, } \\
\text { episodes of weakness, } \\
\text { ataxia, ophthalmoplegia, } \\
\text { and elevated levels of } \\
\text { blood pyruvate }\end{array}$ & $\begin{array}{l}\text { Standard glucose } \\
\text { meal }\end{array}$ & $\begin{array}{l}\text { Ketogenic diet }(2.5: 1 \\
\text { fat: carbohydrate } \\
\text { plus protein) for a } \\
\text { median of } 2.9 \text { years. }\end{array}$ & $\begin{array}{l}\text { Fall in blood pyruvate levels, } \\
\text { a decrease in the frequency } \\
\text { and severity of the episodes } \\
\text { of neurological deterioration, } \\
\text { an increased rate of growth } \\
\text { and development in the } \\
\text { younger brother, and } \\
\text { increased strength and } \\
\text { endurance in the older one. } \\
\text { The treatment had a positive } \\
\text { effect mainly in the areas of } \\
\text { ataxia, sleep disturbance, } \\
\text { speech/language } \\
\text { development, social } \\
\text { functioning, and frequency } \\
\text { of hospitalizations. It was } \\
\text { also safe-except in one } \\
\text { patient who discontinued } \\
\text { because of acute pancreatitis. }\end{array}$ \\
\hline & $\begin{array}{l}\text { Chida et al. } \\
\text { [42] }\end{array}$ & 2018 & A 11-year-old girl & $\begin{array}{l}\text { Medium-chain } \\
\text { triglyceride } \\
\text { (MCT) formula } \\
\text { and a trace } \\
\text { mineral } \\
\text { supplemental } \\
\text { drink. }\end{array}$ & $\begin{array}{l}\text { Ketone formula was } \\
\text { begun at } 50 \mathrm{~g} / \\
1,200 \mathrm{~mL} \text {, four times } \\
\text { per day; the amount } \\
\text { was gradually } \\
\text { increased to } 76 \mathrm{~g} / \\
1,200 \mathrm{~mL} \text {, four times } \\
\text { per day with a } \\
\text { regular checkup of } \\
\text { total ketone body } \\
\text { level. }\end{array}$ & $\begin{array}{l}\text { Seizure frequency markedly } \\
\text { decreased, but the } \\
\text { electroencephalogram } \\
\text { findings, which included a } \\
\text { spike-and-wave pattern } \\
\text { arising from the bilateral } \\
\text { occipital region and } \\
\text { expanding throughout the } \\
\text { region, did not markedly } \\
\text { improve after the } \\
\text { introduction of the KD. }\end{array}$ \\
\hline & $\begin{array}{l}\text { El- } \\
\text { Gharbawy } \\
\text { et al. [43] }\end{array}$ & 2011 & A 15-month-old boy & Breast feeding & $\begin{array}{c}\text { Meals with a } \\
\text { ketogenic ratio (KR) } \\
\text { of } 4: 1 \text { fat (grams): } \\
\text { protein plus } \\
\text { carbohydrate } \\
\text { (grams). Later, to } \\
\text { improve compliance, } \\
\text { the KR of meals was } \\
\text { decreased to } 3: 1 \text {, } \\
\text { and medium-chain } \\
\text { triglyceride (MCT) } \\
\text { oil was added. }\end{array}$ & $\begin{array}{c}\text { Seizures and } \\
\text { hyperventilation ceased. }\end{array}$ \\
\hline \multirow{2}{*}{$\begin{array}{l}\text { Mitochondrial } \\
\text { DNA depletion } \\
\text { syndromes }\end{array}$} & $\begin{array}{l}\text { Joshi et al. } \\
\text { [44] }\end{array}$ & 2009 & $\begin{array}{l}\text { A 31-month-old girl } \\
\text { with Alpers- } \\
\text { Huttenlocher syndrome }\end{array}$ & Usual diet & Ketogenic diet. & $\begin{array}{c}\text { Improvement in clinically, } \\
\text { and her } \\
\text { electroencephalogram } \\
\text { improved dramatically. }\end{array}$ \\
\hline & $\begin{array}{l}\text { Cardenas } \\
\text { et al. }[45]\end{array}$ & 2010 & $\begin{array}{l}\text { A 14-month-old baby } \\
\text { girl with compound } \\
\text { heterozygous } \\
\text { polymerase gamma gene } \\
\text { mutation }\end{array}$ & Usual diet & Ketogenic diet. & $\begin{array}{l}\text { Reduction in seizure } \\
\text { frequency. }\end{array}$ \\
\hline
\end{tabular}

assessed the efficacy and safety of different $\mathrm{KD}$ regimes in patients with intractable childhood epilepsy. All 6 studies showed beneficial effects, especially in reducing the baseline seizure frequency. Findings from these studies are summarized in Table 1 . The adverse side effects of KD included digestive problems such as diarrhea, constipation, vomiting, and issues related to lipid metabolism such as hyperlipidemia, hypercalciuria, and weight loss. The studies conducted thus far had the limitation of small sample size in the pediatric age group [19]. There were 5 randomized control trials [20-24] which were conducted to compare the efficacy between different KD regimes. These studies have compared different $\mathrm{KD}$ regimes by taking into account the efficacy and adverse effects. Findings from these studies are 
summarized in Table 2. A majority of these studies $(n=4)$ have not shown significant differences in efficacy; however, different regimes had different side effect profiles.

Infantile spasms (IS) are a form of epilepsies that occur in infancy and have a characteristic EEG pattern (hypsarrhythmia) accompanied sometimes with intellectual disability and neurodevelopmental regression [1]. Ketogenic diet has been tried with success; however, it has been looked at with reluctance by pediatricians owing to the age of patients and unknown side effects. In a larger study where 104 infants were started on KD after treatment failure with corticosteroids and vigabatrin, it was reported that $64 \%$ saw an improvement in spasms 6 months after starting treatment and $77 \%$ saw improvements following 1-2 years, and adverse effects were reported only in 33\%. However, in 6\%, there was diminished linear growth. They also observed that the older the onset of IS and fewer the anticonvulsant use, the greater the likelihood of improvement of spasms on a KD [25].

In the tuberous sclerosis complex (TSC), a condition frequently associated with epilepsy and infantile spasms; a $\mathrm{KD}$ has been tried with success. In a study spanning 5 years conducted at Johns Hopkins Hospital and Massachusetts General Hospital, 12 children between the ages of 8 and 18 years were started on a KD. Among them, 92\% $(n=11)$ showed a significant $(>50 \%)$ improvement in the initial 6 months itself [26]. In another study, 21 out of 31 patients showed a significant reduction in seizures $(>50 \%)$ in the initial 3 months of initiating a KD [27]. Both studies have concluded that KD appeared to be effective as a therapeutic intervention in intractable pediatric epilepsy in TSC. However, its long-term efficacy needs further evaluation.

\section{Inherited Metabolic Disorders}

3.1. Glycogen Storage Diseases (III and V). Glycogen storage disease type III (GSD III) is an autosomal recessive disease caused by the deficiency of the glycogen debranching enzyme, encoded by the AGL gene. It is characterized by variable liver, cardiac muscle, and skeletal muscle involvement. GSD IIIa is the most common subtype present in about $85 \%$ of affected individuals; it manifests with liver and muscle involvement. GSD IIIb, with liver involvement only, comprises about $15 \%$ of all GSD III [28]. Currently, the treatment to limit glycogen storage is the diet. High-carbohydrate diet prevents fasting hypoglycaemia but increases glycogen storage and does not slow the progression of cardiac and muscular manifestation [29]. Several case reports and case series report beneficial effects on the muscle disease component of GSD IIIa with KD (study details are summarized in Table 3).

GSD V disease is caused by genetic defects of the musclespecific isozyme of glycogen phosphorylase, which blocks ATP formation from glycogen in skeletal muscles [34]. Patients with this rare disease present with exercise intolerance due to blocked glycogen breakdown in skeletal muscles. Introducing alternative fuel substrates, such as ketone bodies (by providing a ketogenic diet), could potentially alleviate muscle symptoms. The summary of case reports relevant to the management of GSD V with $\mathrm{KD}$ is given in Table 3.

\section{Mitochondrial Disorders}

4.1. Pyruvate Dehydrogenase Complex Deficiency. The pyruvate dehydrogenase complex $(\mathrm{PDHc})$ is a member of a family of multienzyme complexes that provides the link between glycolysis and the tricarboxylic acid (TCA) cycle by catalyzing the decarboxylation of various 2-oxoacid substrates to their corresponding acyl-CoA derivatives, $\mathrm{NADH}$, and $\mathrm{CO}_{2}$ [37]. PDHc deficiency is a metabolic disorder commonly associated with lactic acidosis and progressive neurological and neuromuscular degeneration [38]. In 1976, Falk et al. showed that KD would be beneficial in PDHc deficiency $[39,40]$. Since then, several case reports report the efficacy of the KD in the management of this disease (Table 4).

4.2. Mitochondrial DNA Depletion Syndromes (MDS). Mitochondrial DNA depletion syndromes are characterized by a severe, tissue-specific decrease in the mitochondrial DNA (mtDNA) copy number with resulting organ failure. Polymerase gamma (POLG) is one of the enzymes catalyzing mtDNA replication. MDS are phenotypically heterogeneous and usually classified as myopathic, encephalomyopathic, hepatocerebral, or neurogastrointestinal.

\section{Conclusion}

The $\mathrm{KD}$ is an efficacious therapy for pharmacoresistant epilepsy in children, and it should be considered strongly after failure of traditional treatment. It has several gastrointestinal side effects which can be modified with different ketogenic diet regimes. Before prescribing such dietary modifications, it is vital that parents or the caregivers in younger children are able to comprehend and carry out such a nutritional plan intelligently.

The main indications to start with a KD in GSD III patients were cardiomyopathy, skeletal myopathy, or a combination of both, and the KD had good beneficial outcomes according to the existing case reports. Treatment of $\mathrm{KD}$ in mitochondrial diseases also showed promising results in improvement of the clinical picture, but for these diseases, evidence is limited as these diseases are rare, and available evidence is in the form of case reports or case series. Furthermore, carefully designed systematic studies are warranted in patients with rare metabolic diseases to address issues of dietary compliance and the effect of both standard and ketogenic diets on short- and long-term outcomes.

\section{Data Availability}

There are no additional data other than which are mentioned in the article already.

\section{Conflicts of Interest}

The authors declare that they have no conflicts of interest. 


\section{References}

[1] S. Mayorandan, U. Meyer, H. Hartmann, and A. M. Das, "Glycogen storage disease type III: modified Atkins diet improves myopathy," Orphanet Journal of Rare Diseases, vol. 9, no. 1, p. 196, 2014.

[2] S. H. Eun, H. C. Kang, D. W. Kim, and H. D. Kim, "Ketogenic diet for treatment of infantile spasms," Brain and Development, vol. 28, no. 9, pp. 566-571, 2006.

[3] A. L. Rogovik and R. D. Goldman, "Ketogenic diet for treatment of epilepsy," Canadian family physician Medecin de famille canadien, vol. 56, no. 6, pp. 540-542, 2010.

[4] J. Bland, "When is a rare disease not so rare? Implications for medical nutrition therapy," Integrative Medicine (Encinitas, Calif), vol. 15, no. 1, pp. 14-16, 2016.

[5] J. J. Davis, N. Fournakis, and J. Ellison, "Ketogenic diet for the treatment and prevention of dementia: a review," Journal of Geriatric Psychiatry and Neurology, vol. 34, no. 1, pp. 3-10, 2021.

[6] P. R. Huttenlocher, "Ketonemia and seizures: metabolic and anticonvulsant effects of two ketogenic diets in childhood epilepsy," Pediatric Research, vol. 10, no. 5, pp. 536-540, 1976.

[7] E. H. Kossoff, B. A. Zupec-Kania, S. Auvin et al., "Optimal clinical management of children receiving dietary therapies for epilepsy: updated recommendations of the International Ketogenic Diet Study Group," Epilepsia Open, vol. 3, no. 2, pp. 175-192, 2018.

[8] Y.-m. Liu and H.-S. Wang, "Medium-chain triglyceride ketogenic diet, an effective treatment for drug-resistant epilepsy and a comparison with other ketogenic diets," Biomedical Journal, vol. 36, no. 1, p. 9, 2013.

[9] A. Dressler and P. Trimmel-Schwahofer, "The ketogenic diet for infants: how long can you go?," Epilepsy Research, vol. 164, Article ID 106339, 2020.

[10] M. G. Peterman, "The ketogenic diet in epilepsy," Journal of the American Medical Association, vol. 84, no. 26, 1925.

[11] F. Zhu, W. Shan, Q. Xu, A. Guo, J. Wu, and Q. Wang, "Ketone bodies inhibit the opening of acid-sensing ion channels (ASICs) in rat hippocampal excitatory neurons in vitro," Frontiers in Neurology, vol. 10, p. 155, 2019.

[12] T. Li, J. Qin, and X.-P. Chu, "Editorial: ketogenic diet in epilepsy and associated comorbidities," Clinical Efficacy and Mechanisms, vol. 11, no. 66, 2020.

[13] D. M. IJFF, D. Postulart, D. Lambrechts et al., "Cognitive and behavioral impact of the ketogenic diet in children and adolescents with refractory epilepsy: a randomized controlled trial," Epilepsy \& Behavior: E\&B, vol. 60, pp. 153-157, 2016.

[14] A. Dressler, F. Benninger, P. Trimmel-Schwahofer et al., "Efficacy and tolerability of the ketogenic diet versus highdose adrenocorticotropic hormone for infantile spasms: a single-center parallel-cohort randomized controlled trial," Epilepsia, vol. 60, no. 3, pp. 441-451, 2019.

[15] J. A. Kim, J.-R. Yoon, E. J. Lee et al., "Efficacy of the classic ketogenic and the modified Atkins diets in refractory childhood epilepsy," Epilepsia, vol. 57, no. 1, pp. 51-58, 2016.

[16] D. A. J. E. Lambrechts, R. J. A. de Kinderen, J. S. H. Vles, A. J. A. de Louw, A. P. Aldenkamp, and H. J. M. Majoie, “A randomized controlled trial of the ketogenic diet in refractory childhood epilepsy," Acta Neurologica Scandinavica, vol. 135, no. 2, pp. 231-239, 2017.

[17] E. G. Neal, H. Chaffe, R. H. Schwartz et al., "The ketogenic diet for the treatment of childhood epilepsy: a randomised controlled trial," The Lancet Neurology, vol. 7, no. 6, pp. 500-506, 2008.
[18] B. F. M. Wijnen, R. J. A. de Kinderen, D. A. J. E. Lambrechts et al., "Long-term clinical outcomes and economic evaluation of the ketogenic diet versus care as usual in children and adolescents with intractable epilepsy," Epilepsy Research, vol. 132, pp. 91-99, 2017.

[19] M. Janmohamed, M. J. Brodie, and P. Kwan, "Pharmacoresistance - epidemiology, mechanisms, and impact on epilepsy treatment," Neuropharmacology, vol. 168, p. 107790, 2020.

[20] A. G. C. Bergqvist, J. I. Schall, P. R. Gallagher, A. Cnaan, and V. A. Stallings, "Fasting versus gradual initiation of the ketogenic diet: a prospective, randomized clinical trial of efficacy," Epilepsia, vol. 46, no. 11, pp. 1810-1819, 2005.

[21] H.-C. Kang, Y. J. Lee, J. S. Lee et al., "Comparison of shortversus long-term ketogenic diet for intractable infantile spasms," Epilepsia, vol. 52, no. 4, pp. 781-787, 2011.

[22] E. G. Neal, H. Chaffe, R. H. Schwartz et al., "A randomized trial of classical and medium-chain triglyceride ketogenic diets in the treatment of childhood epilepsy," Epilepsia, vol. 50, no. 5, pp. 1109-1117, 2009.

[23] K. N. Raju, S. Gulati, M. Kabra et al., "Efficacy of 4:1 (classic) versus 2.5:1 ketogenic ratio diets in refractory epilepsy in young children: a randomized open labeled study," Epilepsy Research, vol. 96, no. 1-2, pp. 96-100, 2011.

[24] J. H. Seo, Y. M. Lee, J. S. Lee, H. C. Kang, and H. D. Kim, "Efficacy and tolerability of the ketogenic diet according to lipid:nonlipid ratios--comparison of 3:1 with 4:1 diet," Epilepsia, vol. 48, no. 4, pp. 801-805, 2007.

[25] L. Giordano, R. Tambucci, I. E. Cocco et al., "Infantile spasms followed by childhood absence epilepsy: a case series," Seizure, vol. 74, pp. 77-80, 2020.

[26] E. H. Kossoff, E. A. Thiele, H. H. Pfeifer, J. R. McGrogan, and J. M. Freeman, "Tuberous sclerosis complex and the ketogenic diet," Epilepsia, vol. 46, no. 10, pp. 1684-1686, 2005.

[27] S. E. Youn, S. Park, S. H. Kim, J. S. Lee, H. D. Kim, and H.-C. Kang, "Long-term outcomes of ketogenic diet in patients with tuberous sclerosis complex-derived epilepsy," Epilepsy Research, vol. 164, p. 106348, 2020.

[28] A. Dagli, C. P. Sentner, and D. A. Weinstein, "Glycogen storage disease type III," in GeneReviews $\left({ }^{\circledR}\right)$, M. P. Adam, H. H. Ardinger, R. A. Pagon et al., Eds., University of Washington, Seattle, Seattle (WA), USA, 2010.

[29] Copyright (C) 1993-2020, Gene Reviews is a Registered Trademark of the University of Washington, Seattle. All rights reserved.University of Washington, Seattle, Seattle (WA), USA, 1993.

[30] M. Vorgerd, J. Zange, R. Kley et al., "Effect of high-dose creatine therapy on symptoms of exercise intolerance in McArdle disease," Archives of Neurology, vol. 59, no. 1, pp. 97-101, 2002.

[31] A. Brambilla, S. Mannarino, R. Pretese, S. Gasperini, C. Galimberti, and R. Parini, "Improvement of cardiomyopathy after high-fat diet in two siblings with glycogen storage disease type III," JIMD Reports, vol. 17, pp. 91-95, 2014.

[32] F. Francini-Pesenti, S. Tresso, and N. Vitturi, "Modified Atkins ketogenic diet improves heart and skeletal muscle function in glycogen storage disease type III," Acta Myologica: Myopathies and Cardiomyopathies: Official Journal of the Mediterranean Society of Myology, vol. 38, no. 1, pp. 17-20, 2019.

[33] A. Olgac, A. İnci, İ. Okur et al., "Beneficial effects of modified Atkins diet in glycogen storage disease type IIIa," Annals of Nutrition \& Metabolism, vol. 76, pp. 233-241, 2020.

[34] C. P. Sentner, I. J. Hoogeveen, D. A. Weinstein et al., "Glycogen storage disease type III: diagnosis, genotype, 
management, clinical course and outcome," Journal of Inherited Metabolic Disease, vol. 39, no. 5, pp. 697-704, 2016.

[35] T. Marusic, M. Zerjav Tansek, A. Sirca Campa et al., "Normalization of obstructive cardiomyopathy and improvement of hepatopathy on ketogenic diet in patient with glycogen storage disease (GSD) type IIIa," Molecular Genetics and Metabolism Reports, vol. 24, Article ID 100628, 2020.

[36] S. L. W. E. Reason, R. Godfrey, and E. Maguire, "Can a lowcarbohydrate diet improve exercise tolerance in mcardle disease?," Journal of Rare Disorders: Diagnosis \& Therapy, vol. 3, no. 1, 2017.

[37] N. Løkken, K. K. Hansen, J. H. Storgaard, M. C. Ørngreen, R. Quinlivan, and J. Vissing, "Titrating a modified ketogenic diet for patients with McArdle disease: a pilot study," Journal of Inherited Metabolic Disease, vol. 43, no. 4, pp. 778-786, 2020.

[38] S. Bhandary and K. Aguan, "Pyruvate dehydrogenase complex deficiency and its relationship with epilepsy frequency-an overview," Epilepsy Research, vol. 116, pp. 40-52, 2015.

[39] A. Imbard, A. Boutron, C. Vequaud et al., "Molecular characterization of 82 patients with pyruvate dehydrogenase complex deficiency. Structural implications of novel amino acid substitutions in E1 protein," Molecular Genetics and Metabolism, vol. 104, no. 4, pp. 507-516, 2011.

[40] R. E. Falk, S. D. Cederbaum, J. P. Blass, G. E. Gibson, R. A. Kark, and R. E. Carrel, "Ketonic diet in the management of pyruvate dehydrogenase deficiency," Pediatrics, vol. 58, no. 5, pp. 713-721, 1976.

[41] K. Sofou, M. Dahlin, T. Hallböök, M. Lindefeldt, G. Viggedal, and N. Darin, "Ketogenic diet in pyruvate dehydrogenase complex deficiency: short- and long-term outcomes," Journal of Inherited Metabolic Disease, vol. 40, no. 2, pp. 237-245, 2017.

[42] R. Chida, M. Shimura, S. Nishimata, Y. Kashiwagi, and H. Kawashima, "Efficacy of ketogenic diet for pyruvate dehydrogenase complex deficiency," Pediatrics International, vol. 60, no. 11, pp. 1041-1042, 2018.

[43] A. H. El-Gharbawy, A. Boney, S. P. Young, and P. S. Kishnani, "Follow-up of a child with pyruvate dehydrogenase deficiency on a less restrictive ketogenic diet," Molecular Genetics and Metabolism, vol. 102, no. 2, pp. 214-215, 2011.

[44] C. N. Joshi, C. R. Greenberg, A. A. Mhanni, and M. S. Salman, "Ketogenic diet in Alpers-Huttenlocher syndrome," Pediatric Neurology, vol. 40, no. 4, pp. 314-316, 2009.

[45] C. Cárdena, R. A. Miller, I. Smith et al., "Essential regulation of cell bioenergetics by constitutive $\mathrm{InsP}_{3}$ receptor $\mathrm{Ca}^{2+}$ transfer to mitochondria," Cell, vol. 142, no. 2, pp. 270-283, 2010. 